\title{
A DECISION SUPPORT SYSTEM FOR EQUIPMENT ALLOCATION IN A TELEMEDICINE REFERRAL NETWORK
}

\author{
M.J . Treurnicht ${ }^{1} \&$ L. van Dyk $^{2 *}$ \\ ${ }^{1,2}$ Department of Industrial Engineering \\ Stellenbosch University, South Africa \\ 2Ivd@sun.ac.za
}

\begin{abstract}
Telemedicine applications have had much success in strengthening health systems worldwide. Unfortunately, many systems are implemented without decisions based on proper needs assessments. In South Africa, this 'technology push' approach has led to a large amount of equipment standing dormant. It is proposed that the potential of telemedicine be measured prior to implementation, thus 'pulling' the technology towards a clinical need. A decision support system is developed that uses health informatics and computational intelligence to determine the need for telemedicine and to allocate equipment in a network of facilities to achieve the best cost benefit. The system facilitates the collection and storage of electronic health record (EHR) data in a data warehouse. A linear programming model is used with a genetic algorithm. The system was developed and tested for the South African public health sector, using data from 27 hospitals in the Western Cape Province. Results have shown that if telemedicine workstations with specific peripheral equipment, as determined by the algorithm, were implemented in the given period, an estimated R8.7 million in referral costs could have been saved for the 27 hospitals. Thus the case study provided evidence for the benefits of implementation in the chosen network of hospitals. This new application of health informatics could provide telemedicine management with a useful tool for making implementation decisions based on evidence. Future work would include the development of similar systems for other markets.
\end{abstract}

\section{OPSOMMING}

'n Verskeidenheid telegeneeskunde toepassings het reeds groot sukses behaal in die bevordering van gesondheidsdienste wêreldwyd. Ongelukkig word tegnologie dikwels geimplementeer sonder om besluitneming te baseer op behoorlike behoefte bepalings. In Suid-Afrika, het hierdie 'tegnologie stoot' benadering gelei tot ' $n$ groot hoeveelhede ongebruikte toerusting. Daar word voorgestel dat die potensiaal van telemedisyne gemeet moet word, voor implementering, om sodoende tegnologie te 'trek' na kliniese behoefte. 'n Besluitneming ondersteuning stelsel is ontwikkel wat gebruik maak van gesondheidsorg informatika en rekenkundige intelligensie, om die behoefte vir tele-geneeskunde te bepaal en daarvolgens toerusting toe te ken aan ' $n$ netwerk van gesondheidsorg fasiliteite, om die beste kostevoordeel te bereik. Die stelsel fasiliteer die versamel en berg van elektroniese mediese rekord data in ' $n$ data stoor. ' $n$ Lineêre programmering model word gebruik met ' $n$ genetiese algoritme opgelos. Die stelsel is ontwikkel en getoets vir die Suid-Afrikaanse openbare gesondheidsektor, met behulp van data van 27 hospitale in die Wes-Kaap Provinsie. Resultate toon dat indien telemedisyne werkstasies met spesifieke aanvullende toerusting, soos bepaal deur die algoritme, beskikbaar was in die gegewe tydperk, 'n beraamde R8.7 miljoen gespaar kon word met betrekking tot pasiënt verwysingkoste. Die gevallestudie toon dus van die voordele van implementering in die gekose netwerk van hospitale. Hierdie nuwe toepassing van gesondheidsorg informatika kan dien as 'n nuttige hulpmiddel vir tele-geneeskunde besluitnemers in tele-geneeskunde om besluite gebaseer op konkrete bewyse. Toekomstige werk sal die ontwikkeling van soortgelyke stelsels vir ander markte insluit.

\footnotetext{
* Corresponding author

${ }^{1}$ The author was enrolled for an M Eng (Industrial) degree in the Department of Industrial Engineering, Stellenbosch University.
} 


\section{$1 \quad$ INTRODUCTION}

A telemedicine service is a healthcare service ('-medicine') that is delivered over a distance ('tele-'). The interest in the potential of telemedicine to increase the quality, accessibility, utilisation, efficiency, and effectiveness of healthcare services is fuelled by the rapid development of information and communication technology (ICT) and connectivity [1]. The focus of this paper is specifically on the potential of telemedicine to strengthen hospital referral systems by reducing the need to transport patients between facilities [2].

\subsection{Telemedicine service as an alternative to physical hospital referrals}

Health facilities in the public health system are defined according to levels of care. Figure 1 below illustrates the hierarchy of different types of hospitals. More basic levels of care that are not included in the figure include district hospitals and primary health care facilities such as clinics and community health centres. The public health system in South Africa relies on a patient referral system that serves as a crucial link so that all patients have access to higher-levels of care. Patients typically enter the system at a low level, and are only referred when they are in need of more specialised services not offered at the facility. Unfortunately, patient referrals involve risks, and thus they are not always feasible. Transporting patients between facilities also has high cost implications [5]. Telemedicine could aid referral systems by reducing these negative aspects [6].

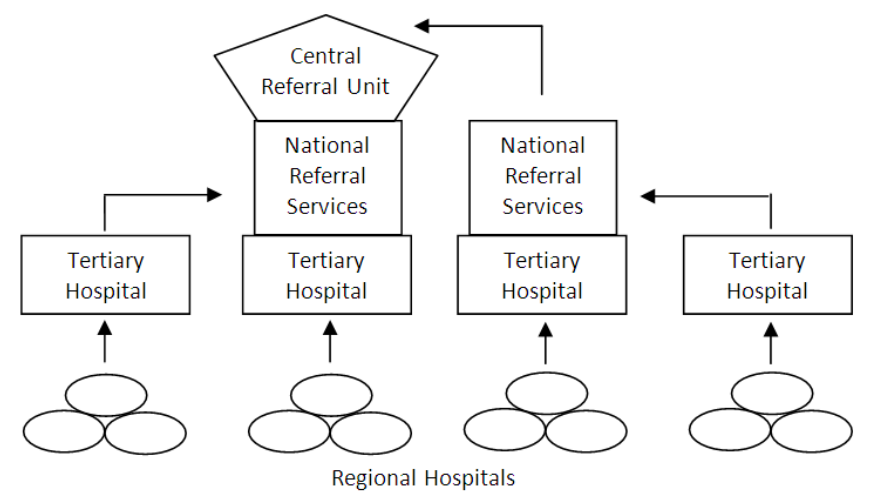

Figure 1: Referral hierarchy in South Africa (Adapted from National Department of Health, 2003)

Without telemedicine, a patient who is diagnosed with an irregular skin rash at a primary health care facility may be referred to a secondary hospital for consultation with a dermatologist. Traditionally the patient has to travel to the hospital to see the dermatologist. However, if the following technology setup were available, this journey would become obsolete: an appropriate digital camera at the clinic, a reliable internet link with sufficient bandwidth, a personal computer at the hospital, and a telephone connection between the dermatologist and the primary care giver. The advantages to the patient and to the health system include reduced transport costs and risk, better utilisation of human and physical resources, and access to quality and timely healthcare.

Store-and-forward (or asynchronous) services involve the transmission of medical data from a patient to a doctor, or from one healthcare worker to another, for assessment at a later time. Real-time (or synchronous) telemedicine services use technology such as videoconferencing and telephones for real-time remote communication. It is not (yet) feasible to use synchronous technologies in the public health sector of South Africa. Many hospitals, especially in the rural areas, do not have reliable internet connections. Low bandwidth also limits the connectivity for real-time consultations. 
The type of technology available at the referring and receiving facilities will determine the type of service that can be delivered. For example, if an electronic cardiogram (ECG) meter is available at the referring facility, and if the receiving facility has the technology to read the ECG, a cardiologist can be consulted without any need to transport the patient. Other examples of enabling equipment are CT scanners, MRI scanners, bronchoscopes, and stethoscopes. In an ideal world all possible telemedicine equipment should be available at all healthcare facilities. However, within the boundaries of financial constraints, the challenge is to allocate the telemedicine equipment to optimise the value of the benefit of these telemedicine services for all patients in the particular health system.

\subsection{Problem statement}

In the public health care system of South Africa, decisions on the procurement and placement of telemedicine equipment are most often not based on the needs within and between particular facilities; a technology-push approach is followed, where the technology is pushed into a system without a proper needs assessment [10]. The preferred alternative, called a clinical-pull strategy, is to base procurement and implementation decisions on a proven clinical need [3]. The lack of a proper needs assessment is often listed as a primary reason for unsustainable telemedicine initiatives [4]. The problem is that the persons who make decisions about the procurement and implementation of telemedicine equipment are often only focused on a particular facility. They lack the decision support that is based on the actual data of the entire system.

\subsection{Purpose}

The purpose of this paper is to describe a decision support system (DSS) that draws on historical electronic health records (EHRs) to support decisions about the allocation of telemedicine equipment for a network of hospitals. The system was specifically developed and validated for the public health sector of South Africa, and is presented in this article as such. However, it is designed to provide a measurement tool, assessing the needs and potential benefits of implementing telemedicine equipment, prior to implementation, within any context.

\section{METHODOLOGY}

The methodology of developing the DSS is based on the framework provided by Turban et al. [8] (refer to Figure 2): data are extracted from existing data sources, which are typically the result of a transactional information system. In this case, the actual data from the district health information systems (DHIS) and electronic healthcare records (EHRs) are used as input, together with reports on equipment specifications and costs, and health indicators.

These data are extracted, transformed, and loaded (ETL) into a data warehouse in which the aggregated data are stored in data marts. For the purpose of this study, four data marts were created: a referral mart, a technology mart, a health indicator mart, and a technology-association mart. These marts provide input data for the data analysis algorithms or mathematical models. In this study, a linear programming mathematical model was developed and solved for this study using the genetic algorithm. This solution will help decision-makers to decide which telemedicine equipment should be procured and implemented at which healthcare facility.

\section{DECISION SUPPORT SYSTEM DESIGN}

\subsection{Data sources}

The opportunities to use healthcare data in decision-making are continually increasing as ICTs evolve. Decision-makers such as healthcare providers and insurance companies rely on data-intensive statistical indicators to make informed decisions. Some of the data that were originally collected to assess provincial and national health indicators are available for 


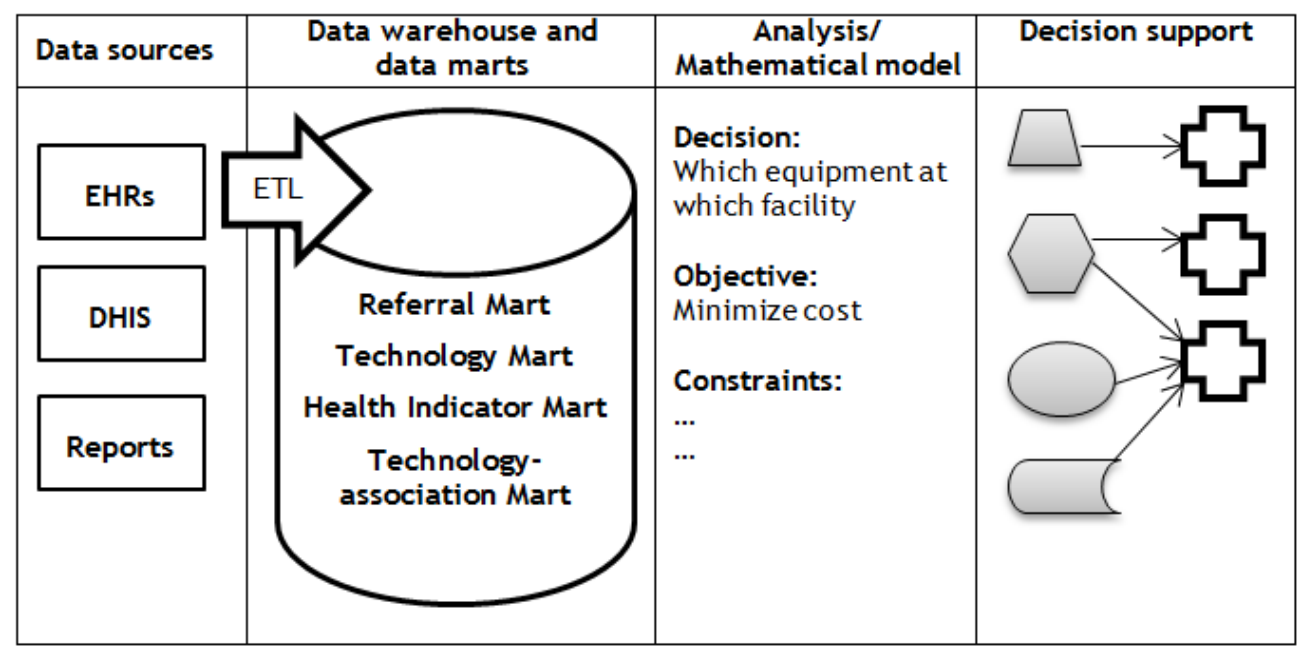

Figure 2: Approach to the development of the DDSs

research studies. However, these data sets, which were intended for health indicators, are mostly of a general nature, and are not always suitable for data mining and artificial intelligence.

Unfortunately, there are limited data available that relate to telemedicine. This can possibly be attributed to the fact that both the telemedicine initiative and computerised health information systems are relatively new in South Africa. Furthermore, since telemedicine needs assessments were mostly done qualitatively, programmes and systems to collect and store quantitative data for telemedicine needs assessments have not yet been introduced. Therefore, finding the appropriate data for the decision support system could be a challenge.

Since there is not much quantifiable data available on telemedicine referrals, other sources were considered that could provide a decision support system with data. Hospital referral data are similar to telemedicine data, since telemedicine could potentially refer patient information electronically. The potential (or need) for using telemedicine can be assessed by focusing on cases where telemedicine could have been used as an alternative to physical patient transfers.

The framework in Figure 2 lists three data sources that are identified as possible sources for telemedicine decision support: District health information systems (DHIS), electronic health records (EHRs), and reports on equipment specifications and costs and health indicators. These are all sources that contain data on patient referrals.

After exploring data sources available for assessment in South Africa, the benefits that can be measured using discharge data from EHRs were separated from those that were not quantifiable using EHR data. Measurements that could quantitatively assess the need for telemedicine, and thus aid in decision-making for implementation, are included in the system, and are listed below:

- Hospital utilisation

- Reduction in transportation cost

- Reduction in human resource cost

\subsection{Data extraction and warehousing}

An integral part of data-based decision support systems is the ability rapidly to analyse large amounts of data from a variety of sources. Data warehouse is the term used for the 
pool of data used by the decision support system [8]. The data warehouse structures integrate data in order to be readily available for decision-makers when needed.

One of the primary goals of telemedicine programmes is to improve the quality of care by referring patient information to specialists, thus reducing the need to transfer patients to another facility. By examining the referral processes in hospitals (prior to telemedicine implementation), the potential of telemedicine to change existing referral processes is assessed. Collecting applicable data from the available data sources could possibly enable decision-makers, using the DSS, to determine the extent to which a telemedicine programme could change the existing referral processes and ultimately healthcare service delivery.

To analyse the data for the needs assessment, the data have to be in a form that would allow the use of mathematical models and other analysis tools. Data are extracted, transformed, and loaded into a data warehouse (Figure 2) before being analysed. Table 1 outlines the data that were used to develop the decision support system.

Table 1: Data used to build the decision support system

\begin{tabular}{|c|c|c|}
\hline & Health indicator data & Referral data \\
\hline Description & $\begin{array}{l}\text { General statistics of the hospitals. } \\
\text { Indications of the size and workload of the } \\
\text { hospital }\end{array}$ & $\begin{array}{l}\text { Referral data of patients that have been } \\
\text { referred from one hospital to another }\end{array}$ \\
\hline Population & Department of Health Hospitals: DHIS, EHR & Department of Health Hospitals: DHIS, EHR \\
\hline $\begin{array}{l}\text { Collecting } \\
\text { methods }\end{array}$ & Request extraction from EHR database & Request extraction from EHR database \\
\hline $\begin{array}{l}\text { Data } \\
\text { attributes }\end{array}$ & $\begin{array}{l}\text { - } \text { Number of beds } \\
\text { - } \text { Patient day equivalent } \\
\text { - } \text { Cost per patient day } \\
\text { - } \text { Bed utilisation rate } \\
\text { - Transfer distances } \\
\text { - } \text { Patient transfer cost }\end{array}$ & $\begin{array}{ll}\text { - } & \text { Diagnosis } \\
\text { - } & \text { Referral reason } \\
\text { - } & \text { 'Referred to' hospital } \\
\text { - } & \text { 'Referred from' hospital } \\
\text { - } & \text { Date admitted } \\
\text { - } & \text { Date of discharge } \\
\text { - } & \text { Patient date of birth } \\
\text { - } & \text { Patient gender } \\
\text { - } & \text { Patient suburb } \\
\end{array}$ \\
\hline Analysis & - Economic analysis & $\begin{array}{l}\text { - Statistical analysis } \\
\text { - Referral mapping }\end{array}$ \\
\hline
\end{tabular}

\subsection{Mathematical model}

The calculation of potential telemedicine implementation savings becomes complex when there is an increase in the variety of telemedicine equipment and the number of hospitals under consideration. A combination of devices influences the type of diagnostics that can be done using telemedicine systems. Decisions about the nature of telemedicine devices to be implemented should therefore be integrated with specific reference to the influence on expected implementation costs and savings.

In order to acquire maximum cost benefits, the selection of telemedicine devices at a number of hospitals is modelled as a mixed integer programming problem, and is formulated as follows:

\section{Indices:}

$i=1,2,3 \ldots n$ Device index

$j=1,2,3, \ldots m$ Hospitals 'referred from' index (for which referral reports were collected)

$k=1,2,3, \ldots p \quad$ Hospitals 'referred to' index

$l=1,2,3, \ldots q$ Diagnosis (ICD10) index 


\section{Decision variable:}

$x_{i, j}= \begin{cases}1, & \text { Device } i \text { is chosen to be implemented at hospital } j \\ 0, & \text { Device } i \text { is not chosen to be implemented at hospital } j\end{cases}$

\section{Input parameters (independent of decision variable):}

$y_{i, j}=\left\{\begin{array}{l}1, \text { Device } i \text { is already available at hospital } j \text { when decision is made } \\ 0, \text { Device } i \text { is not already available at hospital } j \text { when decision is made }\end{array}\right.$

$d_{i, l}=\left\{\begin{array}{l}1, \text { Device } i \text { is required to diagnose a case recorded as ICD10 code } l \\ 0, \text { Device } i \text { is not required to diagnose a case recorded as ICD10 code } l\end{array}\right.$

$h_{j, k, l}=$ Amount of times that diagnosis $I$ was referred from hospital $j$ to hospital $k$

$c_{i}=$ Annual payments to implement and maintain device $i$

$b_{j, k}=$ Difference in overnight cost if a patient stayed in hospital $j$ and not hospital $k$

$t_{j, k}=$ Transport distance to transfer a patient from hospital $j$ to hospital $k$

$u=$ Patient transport cost per $\mathrm{km}$

$w=$ Total annual payment cost available to implement devices

$g_{j, k}= \begin{cases}1, & \text { Hospital } j \text { is of the same or lower level than hospital } k \\ 0, & \text { Hospital } j \text { is a higher referral level than hospital } k\end{cases}$

\section{Variable parameters (influenced by decision variable):}

- Devices $\mathrm{i}$ that will be available at hospital $\mathrm{j}$ are a combination of what was available prior to implementation and the devices that are chosen to be implemented.

$V_{i, j}\left\langle x_{i, j} \mid y_{i, j}\right\rangle=\left\{\begin{array}{l}1, \text { Device } i \text { will be available after implementation at hospital } j \\ 0, \text { Device } i \text { will not be available after implementation at hospital } j\end{array}\right.$

$V_{i, j}=x_{i, j}+y_{i, j} \quad i=1,2,3, \ldots n ; j=1,2,3, \ldots m$

- $\quad$ The annual payments are calculated for the devices chosen at each hospital.

$C_{i, j}\left\langle x_{i, j} \mid c_{i}\right\rangle=$ Annual payment costs to implement device $i$ at hospital $j$

$C_{i, j}=x_{i, j} * c_{i} \quad i=1,2,3, . . n ; j=1,2,3, \ldots m$

- The number of referrals that have the potential to be telemedicine referrals, with the chosen devices, is calculated for each hospital $j$. Each ICD-10 case requires a unique combination of devices for diagnosis. Thus a referral recorded in $2010, \mathrm{~h}_{\mathrm{j}, \mathrm{k}, \mathrm{l}}$ is only a potential telemedicine referral if all the devices that are required to diagnose I at that hospital are available after implementation:

$R_{j, k}\left\langle V_{i, j}\left|d_{i, l}\right| h_{j, k, l} \mid g_{j, k}\right\rangle=$ Number of telemedicine referrals from hospital $j$ to hospital $k$

$$
R_{j, k}=\left\{\begin{aligned}
0, & V_{i, j}<d_{i, l}, \\
\sum_{l=1}^{q} h_{j, k, l} \cdot g_{j, k}, & V_{i, j} \geq d_{i, l} \quad \text { for all } i=1,2,3, . . n
\end{aligned}\right.
$$

- The expected travel cost savings between hospital $\mathrm{j}$ and hospital $\mathrm{k}$ is calculated as a product of the determined number of potential referrals, the transport distances, and the cost per $\mathrm{km}$.

$T_{j, k}\left\langle R_{j, k}\left|t_{j, k}\right| u\right\rangle=$ Travel cost savings from hospital $j$ to hospital $k$ with proposed devices

$T_{j, k}=R_{j, k} * t_{j, k} * u \quad j=1,2,3, \ldots m ; k=1,2,3, \ldots p$ 
- The expected savings that are credited to patients staying in hospitals with a lower daily cost are calculated as a product of the number of potential referrals determined in (3), and the difference in hospitalisation costs between hospital $\mathrm{j}$ and hospital k. $B_{j, k}\left\langle R_{j, k} \mid b_{j, k}\right\rangle=$ Hospitalisation savings, patients staying at hospital $j$ and not hospital $k$ $B_{j, k}=R_{j, k} * b_{j, k} \quad j=1,2,3, . . m ; k=1,2,3, \ldots p$

\section{Objective function:}

The objective is to maximise the cost savings ( $z$ ) that can be expected when choosing telemedicine devices to be implemented in the various referral hospitals. The annual payment costs, transport cost savings, and hospitalisation savings are all functions of the decision variable. These costs and savings are therefore variables determined by the decision variable. The objective function is to choose a decision variable that will maximise the sum of the savings with the subtracted cost.

$\max z=-\sum_{i=1}^{n} \sum_{j=1}^{m} C_{i, j}+\sum_{j=1}^{m} \sum_{k=1}^{p} T_{j, k}+\sum_{j=1}^{m} \sum_{k=1}^{p} B_{j, k}$

\section{Subject to:}

1. A device should not be implemented if it is already available at that hospital.

$$
x_{i, j}+y_{i, j} \leq 1 \quad i=1,2,3, \ldots n ; j=1,2,3, \ldots m
$$

2. The total annual payment cost is constrained.

$$
\sum_{i=1}^{n} \sum_{j=1}^{m} c_{i, j} \leq \mathrm{w}
$$

\subsection{Using the genetic algorithm to solve the model}

Heuristic methods are good alternatives to solving problems for which exhaustive search methods are impractical. A genetic algorithm is a search-heuristic that mimics evolutionary principles by iteratively searching for the best solution to the problem. The genetic algorithm was chosen and developed specifically for the decision support system in order to find a solution to the formulated problem. Microsoft Excel was chosen as the computing platform, together with Visual Basic as the programming language, based on the practical implications for the South African Department of Health. The genetic algorithm is integrated with the rest of the decision support system to provide better usability.

Optimisation problems require both variety and progression. Natural phenomena, therefore, provide valuable principles for algorithms. Genetic algorithms mimic the biological theory of evolution, where plant and animal species breed to form new offspring with unique features. With the birth of a new offspring, a new generation is formed. The concept of evolution is that new generations possess different characteristics from the previous generation, with the capability of improved performance in the new environment. The 'survival of the fittest' principle is applied so that, with the passage of time, new generations become stronger by abandoning weaker individuals. Mutations, which occur randomly, reduce the possibility of inbreeding and lower the chances of the population being trapped at a local optimum [9].

\section{Initiation}

The initial population consists of a number of feasible trial solutions. Each individual solution in the population is created randomly and repaired to meet the set of constraints. For example, a population for the decision variable $x_{i, j}$ would consist of a number of trial solutions that are repaired to ensure that a device is not chosen for a hospital where such a device is already available.

A basic feasible solution consists of a number of genes (with a value of 0 or 1 ), indicating the chosen devices for the hospitals. The genes determine the strength of the individual. 
Genes that form combinations of devices resulting in high cost savings and low implementation costs would have a high fitness (value of the objective function) outcome. The fitness is calculated for each feasible member of the initial population.

Solving highly constrained problems with genetic algorithms can be complex. One reason for this is that the generation of new offspring does not allow for constraint consistency through crossover. Hence, through crossover, the birth of a new offspring does not necessarily allow for a new feasible solution. The new offspring has to meet the requirements of the constraints before it can be considered a possible solution [10]. Nevertheless, the formulated problem is not highly constrained, making the genetic algorithm a practical approach.

\section{Iterations}

During the iteration phase, new basic feasible solutions are created using the characteristics of good existing solutions. Parents (basic feasible solutions in the population) are randomly selected and compete in a tournament to mimic natural selection. Two parents with relatively high levels of fitness are chosen and paired with each other in a multiple crossover process to form an offspring (new basic feasible solution). Crossover points are chosen at random, so that if two parents were to pair more than once, different offspring would be created. Offspring inherit a combination of both parents' genes; thus a different combination of genes from the same parents would result in a different child. Mutation occurs on a random basis to increase the stochasticity of the algorithm, allowing a new offspring to be generated with unique genes that do not belong to either parent.

New offspring are subject to the same set of constraints, ensuring that it is a feasible solution. If a new offspring is created that does not fit the criteria, making it unfeasible, the solution (offspring) is repaired in the same way that the individuals of the original population were repaired. The fitness of each offspring is calculated when the algorithm searches through the EHR data to calculate the cost (savings) for each basic feasible solution. As the process evolves, the fitness of the population increases. This process of creating new offspring continues until the termination criterion is met.

\section{Termination rule}

Since there are a large number of feasible solutions, the algorithm will continue to search through the solution space until a stopping condition is met, indicating that it has found a near-optimum. A number of different termination rules can be used, such as a fixed computation time, a fixed number of iterations, or a fixed number of consecutive iterations without improvement. If the algorithm is executed for an adequate time period, the entire population will have the same fitness. If no new offspring are created during a number of iterations, it can be assumed that the algorithm has found a near-optimum solution. Therefore, when reaching the termination criterion, the solution space would have converged on the final solution. The algorithm stops after a number of consecutive iterations do not improve. This number can be changed if more certainty is required that the algorithm has reached its best solution.

\section{CASE STUDY}

The system was developed and tested for the South African public health sector, using data from 27 hospitals in the Western Cape Province. These data were extracted during 2011 from the Clinicom hospital information system. The Western Cape Department of Health provided ethical clearance for the data to be used for purposes of this study. 


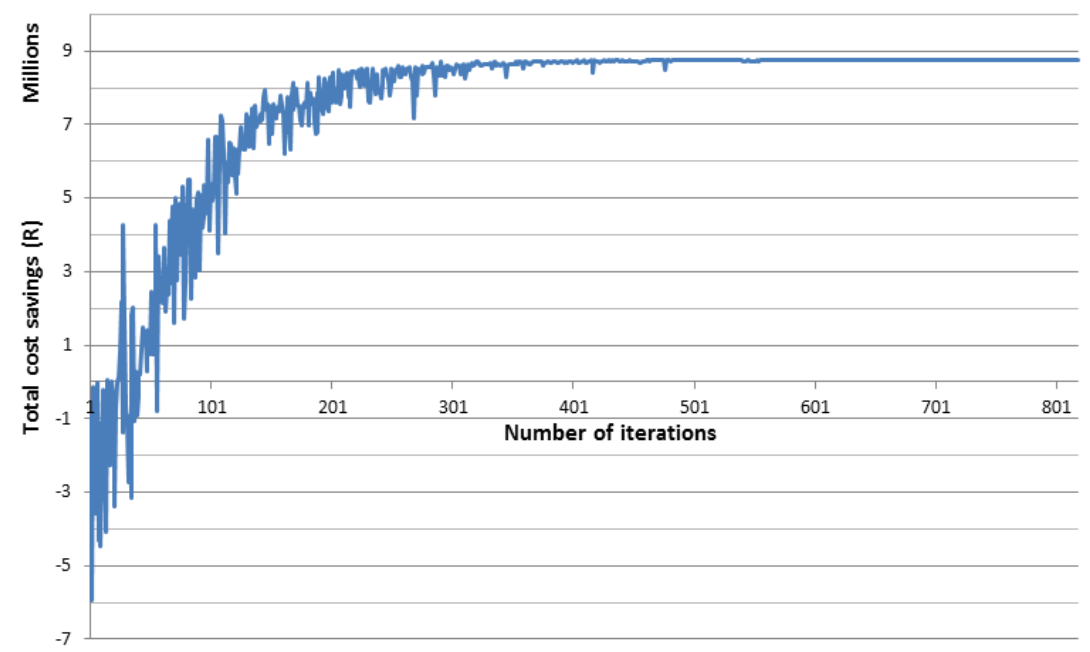

\section{Figure 3: Equipment allocation algorithm iteration results on potential telemedicine} cost savings

The genetic algorithm iteration results of the algorithm are shown in Figure 2. Between the $1^{\text {st }}$ and the $200^{\text {th }}$ iteration, there was a large stochastic element in the basic feasible solutions' (bfs) objective functions. The reason for this is that the genetic algorithm starts with a random population that is improved by randomly pairing basic feasible solutions with high objective functions. As a result, as iterations increase, the stochasticity decreases and the objective functions increase.

The algorithm was programmed to stop after 200 consecutive iterations had showed no improvement. Table 2 is an extract from the $i x j$ matrix that contains the full solution. For example, the value of the decision variable $x_{i j}=x_{71}=x_{74}=x_{75}=1$ indicates that for this solution, George hospital should be equipped with a basic telemedicine workstation, a telestethoscope, and an ECG machine. This solution suggests an estimated potential cost savings, when implementing the equipment, of R8.7 million. This is not necessarily the optimum solution; however, it is strongly recommended that this good solution be implemented.

The results from this case study are unique to the types of referrals between these hospitals for the given time period. However, since referrals are largely influenced by the services hospitals provide, it can be expected that referral patterns for these hospitals would be similar in the future, thus making the implementation suggestions (based on historical data) relevant into the future.

\section{CONCLUSION AND RECOMMENDATION}

In this study, a clinical-pull approach to telemedicine equipment allocation was proposed, using health informatics to determine the need for telemedicine before implementation. The decision support system was developed to support strategic implementation decisions concerning the potential of telemedicine as an alternative to hospital referrals within the public health sector of South Africa. The system serves as a tool to identify, assess, and use the potential benefits of telemedicine systems in management implementation planning.

The novelty of using EHR data to measure the potential benefits of telemedicine implementation called for an exploratory study to consider decision support systems, different applications of telemedicine, and the data sources available. The decision support system was subsequently based on a new concept of using patient discharge data to quantify potential benefits for implementation. 
Table 2: DSS algorithm implementation decisions

\begin{tabular}{|c|c|c|c|c|c|c|c|c|}
\hline Hospital name & $\begin{array}{l}\text { Basic } \\
(i=1)\end{array}$ & $\begin{array}{c}\text { Camera } \\
(\mathrm{i}=2)\end{array}$ & $\begin{array}{c}\text { Bronchoscope } \\
(i=3)\end{array}$ & $\begin{array}{l}\text { Stethoscope } \\
\qquad(i=4)\end{array}$ & $\begin{array}{l}\text { ECG } \\
(i=5)\end{array}$ & $\begin{array}{l}X \text { ray } \\
(i=6)\end{array}$ & $\begin{array}{c}\text { CT Scan } \\
(i=7)\end{array}$ & $\begin{array}{c}\text { MRI } \\
(i=8)\end{array}$ \\
\hline Alexandra $(j=1)$ & 0 & 0 & 0 & 0 & 0 & 0 & 0 & 0 \\
\hline Brewelskloof $(j=2)$ & 0 & 0 & 0 & 0 & 0 & 0 & 0 & 0 \\
\hline Brooklyn Chest $(j=3)$ & 1 & 0 & 0 & 1 & 0 & 1 & 0 & 0 \\
\hline DP Marais $(\mathrm{j}=4)$ & 0 & 0 & 0 & 0 & 0 & 0 & 0 & 0 \\
\hline Eerste River $(j=5)$ & 1 & 1 & 0 & 0 & 0 & 0 & 0 & 0 \\
\hline False Bay $(j=6)$ & 1 & 1 & 0 & 0 & 0 & 0 & 0 & 0 \\
\hline George $(j=7)$ & 1 & 0 & 0 & 1 & 1 & 0 & 0 & 0 \\
\hline GF J ooste $(j=8)$ & 1 & 1 & 1 & 1 & 1 & 0 & 1 & 0 \\
\hline Groote Schuur (j=9) & 1 & 0 & 0 & 0 & 0 & 0 & 0 & 0 \\
\hline Harry Comay $(j=10)$ & 0 & 0 & 0 & 0 & 0 & 0 & 0 & 0 \\
\hline Helderberg $(\mathrm{j}=11)$ & 1 & 0 & 1 & 1 & 1 & 0 & 1 & 0 \\
\hline Karl Bremer $(j=12)$ & 1 & 1 & 1 & 1 & 1 & 0 & 1 & 0 \\
\hline
\end{tabular}

The mixed integer programming problem was formulated and solved using a genetic algorithm. This new approach proved to be effective in choosing equipment for implementation that could provide high cost benefits for a network of hospitals. Future work could include using other heuristics to solve the problem. The problem could also be expanded to include other quantifiable benefits for telemedicine implementation. Although the system was specifically developed for the South African public sector, it could be modified to be used in different health systems.

\section{ACKNOWLEDGMENTS}

The authors thank the National Research Foundation as the main funder of this research, the Eastern and Western Cape Departments of Health, and Jill Fortuin from the South African Medical Research Council for their support in this research.

\section{REFERENCES}

[1] Clarke, M. \& Thiyagarajan, C.A. 2008. A systematic review of technical evaluation in telemedicine systems. J ournal of Telemedicine and e-Health, pp. 170-183.

[2] Bashshur, R., Shannon, G. \& Sapci, H. 2005. Telemedicine evaluation. Telemedicine and eHealth, pp. 296-317.

[3] Wyatt, J.C. 1996. Commentary: Telemedicine trials - clinical pull or technology push? British Medical J ournal, p. 1380.

[4] Broens, T.H., Huis in't Veld, R.M., Vollenbroek-Hutten, M.M., Hermens, H.J., van Halteren, A.T. \& Niewenhuis, L.J. 2007. Determinants of successful telemedicine implementations: A literature study. J ournal of Telemedicine and Telecare, pp. 303-309.

[5] Hensher, M., Price, M. \& Adomakoh, S. 2006. Referral hospitals. In D. Jamison, J. Breman, A. Measham, G. Alleyne, M. Claeson, \& D. Evans, Disease control priorities in developing countries, second edition, New York: Oxford University Press, pp. 1229-1244.

[6] Bashshur, R.L., Reardon, T.G. \& Shannon, G.W. 2000. Telemedicine: A new health care delivery system. Annual Review Public Health, pp. 613-637.

[7] Della Mea, V. 2005. Prerecorded telemedicine. Journal of Telemedicine and Telecare, pp. 276284.

[8] Turban, E., Aronson, J., Liang, T.-P. \& Sharda, R. 2007. Decision support and business intelligent systems, eighth edition. New J ersey: Pearson Prentice Hall.

[9] Hillier, F.S. \& Lieberman, G.J . 2005. Introduction to operations research, Singapore: McGrawHill.

[10] Aickelin, U. \& Dowsland, K.A. 2003, An indirect genetic algorithm for a nurse scheduling problem, Computers \& Operations Research, pp. 761-778. 